\title{
Species Diversity and Carbon Stock Assessments in Mangrove dan Buffer Zone Conservation Areas, West Papua, Indonesia
}

\author{
Daril Andrean Davinsa, Waskito Aji Suryo Putro, Dyah Putri Utami \\ Kilang Pertamina Internasional Refinery Unit VII Kasim, Universitas Pendidikan Muhammadiyah Sorong, \\ Universitas Diponegoro, \\ jokosyukur@pertamina,waskito_asp@ymail.com,dyah.utami@arjunawijaya.com
}

\author{
Abstract \\ Species Diversity and Carbon Stock Assessments in Mangrove dan Buffer Zone Conservation Areas, \\ West Papua, Indonesia
}

Global warming is the foremost natural issue nowadays. the number of community or companies that are beginning to not consider natural standards is accelerating global warming. PT Pertamina Refinery Unit VII Kasim with a mangrove conservation area and buffer zone has a role in reducing the impact of global warming. This can be a potential for carbon stock and absorption in conservation areas. Carbon research can also be linked to world carbon trading, as a form of commitment from a country that does not have forests. This study aims to determine the results of carbon stock and absorption in the mangrove area and buffer zone. This research was conducted in July 2021 in the company's conservation area. The diversity of species mangrove with 5 results and 13 species in bufferzone areas. The carbon results obtained, that the two conservation areas have great potential in absorbing and storing carbon. The result of carbon stock in the mangrove area is 32.93 tons/ha and in the buffer zone area is 588.86 tons/ha. While the carbon absorption in the mangrove ecosystem is 8.97 tons/ha and in the buffer zone area is 160.45 tons/ha. In carbon trading, the Pertamina RU VII Program has the potential to contribute to the country as much as (1.6 billion).

Keyword : Carbon Trading, Carbon Stock and $\mathrm{CO}_{2}$

\section{Introduction}

Global warming is a trending topic that is often discussed by the world community. Increased Co2 in the air has created global warming whose immediate effects can be felt by humanity. This is because of the many community activities that begin not to consider the principles of the environment in everyday life.

One alternative in controlling climate change is to reduce greenhouse gas emissions, namely by maintaining the integrity of natural forests and increasing the population density of trees outside the forest(Oktaviona et al., 2017). Forests will be a source of greenhouse gas emissions at a time when they are not managed properly.

Donato et al. (2011) which states that mangroves have the ability to assimilate and high rate of carbon sequestration. Measuring the amount of carbon stored in the body of a living plant on a land can describe the amount of $\mathrm{CO}_{2}$ in the atmosphere absorbed by plants.

Mangrove conservation area and buffer zone area of PT Pertamina Refinery Unit VII in Kasim, Sorong, West Papua has the potential to absorb carbon. The potential for diversity of tree species in conservation areas has not been well identified. The land is currently only used as a conservation area for RU VII companies, where the type of trees in the conservation area has the potential value of stored carbon stocks and is able to contribute to environmental issues. To identify species and estimate stored carbon stocks, this research is necessary, so that companies are able to identify tree species and evaluate new programs and efforts to preserve conservation areas.

\section{Materials and Methods}

This data collection was carried out in July 2021 at the mangrove conservation area and buffer zone area of the company, PT. Pertamina RU VII Kasim, West Papua Province. Research using survey methods, and the determination of research stations is done by purposive sampling (Sugiyono, 2008). The location consideration of the area that has been determined as a conservation area by Pertamina General Manager RU VII Kasim. The location of the data collection can be seen in the image below. 


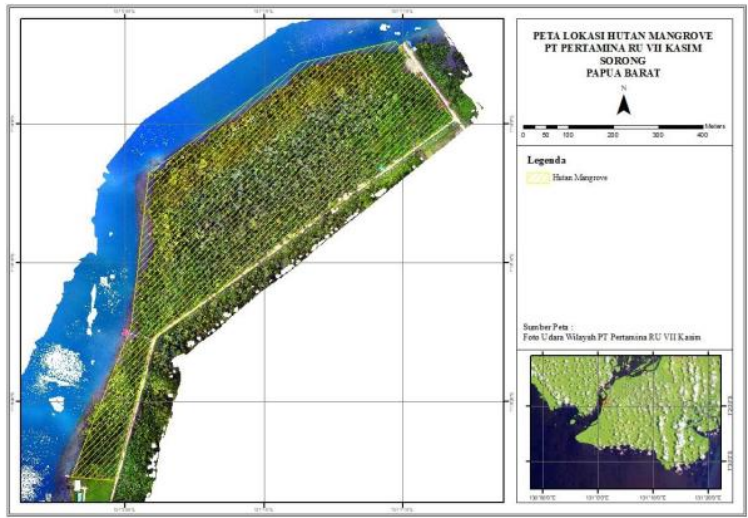

Figure 1. Mangrove Conservation Area and Commensurate Beach PT. Pertamina RU VII Kasim.

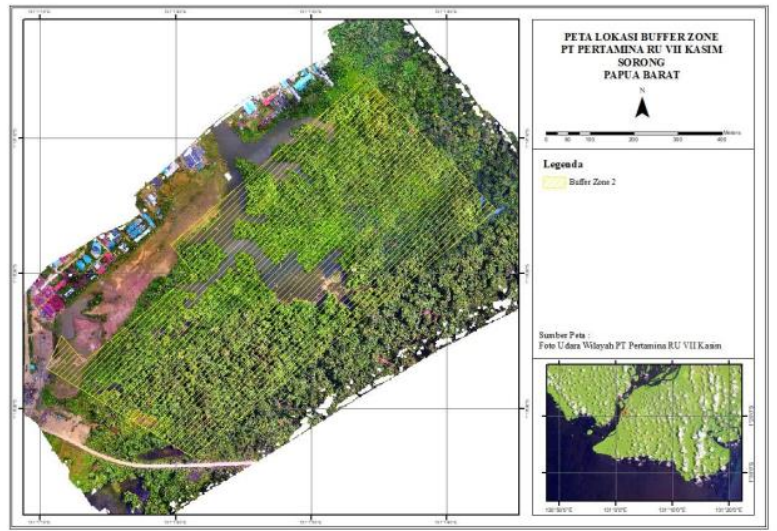

Figure 2. Buffer Zone Conservation Area PT. Pertamina RU VII Kasim.

The area of data collection locations in mangrove conservation areas is $10.5 \mathrm{Ha}$ and buffer zone area is $38.5 \mathrm{Ha}$.

\subsection{Data and Sample Calling Methods}

Sampling is done using the quadrant transect method. Soil sampling and soil organic carbon content measurement methods in soil refer to the National Standardization Agency (2011).

The restoration of carbon reserves is done by calculating the volume of trees and then converted to biomass using allometric methods. The result of tree biomass obtained is further converted into carbon uptake value (ton / tree) by multiplying the conversion factor by 0.47 and every 1 ton of carbon stored in the tree is able to absorb carbon dioxide $_{(\mathrm{CO} 2)}$ as much as 3.67 tons (IPCC, 2006).

\subsection{Flora Inventory Method}

The method of inventory of mangrove trees and buffer zone forest trees is carried out using Djamaluddin mangrove identification book (2018). The established data obtained were analyzed to calculate the Important Value Index (INP), shanon-Weiner Type Diversity Index (H'), Type Leveling Index (E) and Type Dominance Index (C). The Important Value Index (INP) is the result of the sum between relative density (KR) and relative frequency (FR). Calculation of KR and FR using the following formulas (Soerianegara and Indrawan 2002):

1. Density Type (K): Number of Individuals/Area of Plots

2. Realtive Density (KR): Density of All Types X 100\%

3. Frequency type (F): Number of plots/total number of plots

4. Relative Frequency (FK): Frequency of Type/Frequency of All Types X 100\%

5. Type Dominance (D): Number of individuals/Total number of all types of individuals

6. Relative Dominance (DR): Dominance of a Type/Dominance of All Types X 100\% 
The important value index (INP) of the seed strata and stake is INP $=\mathrm{KR}+\mathrm{FR}$. For tree strata is INP $=\mathrm{KR}+\mathrm{FR}+$ DR.

\subsection{Carbon dioxide Gas Uptake Analysis Method (CO2)}

This calculation is done using references from Qian et al. (2008) namely:

\section{$\mathrm{SCO}_{2}=\mathrm{Mr} . \mathrm{CO}_{2} / \mathrm{ArCxKc}$}

Information:

$\mathrm{SCO}_{2} \quad$ : Serapan gas $\left(\mathrm{CO}_{2}\right)$.

$\mathrm{Mr}_{\mathrm{CO} 2:}$ The relative molecular weight of the $\mathrm{C}$ atom, which is 12 .

Kc: Carbon Content.

\subsection{Method of Carbon dioxide Gas Uptake Analysis (CO2)Per Hectare}

This calculation is carried out in accordance with the National Standardization Agency (2011). Calculation of $\mathrm{CO}_{2}$ gas per hectare using the following formula:

\section{$\mathrm{Sn}=\mathrm{SCO}_{2} / 1000 \times 1000 / \mathrm{L}$ plot}

Information:

Sn: Gas uptake $(\mathrm{CO})$ per hectare (tonsof $\mathrm{CO}_{\mathrm{CO}} / \mathrm{Ha}$ ).

CO2: $\quad$ The carbon content of each carbon pool $(\mathrm{kg})$.

L Plot: Plot area on each carbon pool (m2).

\subsection{Carbon Reserve Analysis Method}

This calculation is carried out in accordance with the National Standardization Agency (2011). The formula is as follows:

\section{$\mathrm{Cn}=\mathrm{Cx} / 1000 \times 1000 / \mathrm{L}$ plot}

Information:

Cn: Carbon Reserves per Hectare $(\mathrm{Kg} / \mathrm{Ha})$.

Cx: The carbon content of each carbon pool $(\mathrm{kg})$.

L Plot: Plot area on each carbon pool (m2).

\subsection{Organic Ingredient Analysis Methods}

This calculation is carried out in accordance with the National Standardization Agency (2011). The formula is as follows:

Information:

\section{$\mathrm{Ct}=\mathrm{Kd} \times \mathbf{p} \times \%$ C organic}

Ct: Soil organic carbon content $(\mathrm{g} / \mathrm{cm} 2)$.

Kd: Soil depth $(\mathrm{cm})$.

Q: Density $\left(\mathrm{g} / \mathrm{cm}^{3}\right)$.

$\%$ : Organic C or percentage value of carbon content $(0.47)$.

\subsection{Total Carbon Reserves}

This calculation is carried out in accordance with the National Standardization Agency (2011). The formula is as follows:

$$
C_{\text {total }}=C_{n}+C_{\text {soil }}
$$

$\mathrm{C}_{\text {total: }} \quad$ Total Carbon Reserve (ton/Ha).

$\mathrm{C}_{\mathrm{n}}$ : Carbon content per hectare in each carbon pool (ton / Ha).

Soil C: Organic carbon content of soil per hekatar (ton/ha). 


\section{Results}

\subsection{Species Inventory Results of Mangrove Conservation Area}

Based on the results of observations, in conservation areas located on the coast in the area of PT. Pertamina (Persero) RU VII Kasim has a forest that is Mangrove Forest. These forest formations have the same type and characteristics. Mangrove forests in conservation areas have 5 types of plant species. The results of the data collection of mangrove species and densities in mangrove conservation areas can be seen in the table below.

Table1. Inventory results and density of mangrove trees

\begin{tabular}{cccc}
\hline Local Name & Latin name & Number of Individuals & Density \\
\hline Man Mangroves & Rhizopora mucronata & 8000 & 0,07 \\
Mangrove Urap & Rhizopora stylosa & 8500 & 0,08 \\
Ketapang & Terminalia catappa & 50 & 0,0004 \\
Pedada & Sonneratia alba & 81 & 0,0007 \\
Could & Bruiguiera gymnorrizha & 2300 & 0,02 \\
\hline
\end{tabular}

The results of data on the density of mangrove trees in conservation areas found that the highest density in rhizopora stylosa species with an individual number of 8500 and a density of 0.08 . While the lowest value in mangrove species found in the Terminalia catappa type with an individual number of 50 and a density value of 0.0004 .

\subsection{Index Distribution Results in Mangrove areas}

The distribution of mangrove species has different values for each species. The results are contained in the table in the form of index values. The results of the index calculation can be seen in the table below.

Table2. Mangrove Tree Index Value Distribution Results

\begin{tabular}{ccccccccc}
\hline Local Name & Latin name & K & KR\% & F & FRI & D & DR\% & $\begin{array}{c}\text { FOR } \\
\text { EXAMPLE }\end{array}$ \\
\hline Man Mangroves & Rhizophora mucronata & 300 & 42,25 & 60 & 43 & 1,02 & 8,96 & 91,2 \\
Mangrove Wrap & Rhizophora stylosa & 230 & 32,29 & 30 & 23 & 1,02 & 39,7 & 60,3 \\
Ketapang & Terminalia catappa & 140 & 19,72 & 20 & 18 & 1,27 & 32,8 & 20,7 \\
Perdida & Sonneratia alba & 10 & 2,87 & 5 & 8 & 1,02 & 8,96 & 13 \\
Could & $\begin{array}{c}\text { Bruiguiera } \\
\text { gymnorrizha }\end{array}$ & 10 & 2,87 & 5 & 8 & 1,08 & 9,52 & 13 \\
\hline \multicolumn{1}{c}{ Total } & & 690 & 100 & 120 & 100 & 1,41 & 100 & 200 \\
\hline
\end{tabular}

The results of observations are known that the highest relative density is found in mangrove trees with Rhizophora mucronata with a value of KR\% of 42.25 with an important value of 91.2. While the lowest relative density value is found in the tree species Sonneratia alba and Bruiguiera gymnorrizha with the same value KR\% of 2.87 and Important Value of 13.00 .

\subsection{Species Inventory Results of Buffer Zone Conservation Area}

Buffer zone area is a natural forest area that is around the company's work area. Natural forest areas are still quite maintained in ecosystem conditions, judging from the various types of plants found in the forest area. Based on the results of observations made, found various types of plants in natural forest areas are located in the area of PT. Pertamina (Persero) RU VII Kasim. There are 13 types of trees presented in Table 2 below. 
Table3. Tree Inventory Results in a buffer zone

\begin{tabular}{llcc}
\hline \multicolumn{1}{c}{ Local name } & \multicolumn{1}{c}{ Latin name } & $\begin{array}{c}\text { Number of } \\
\text { Individuals }\end{array}$ & Density \\
\hline Wants tuba & Derris elliptica & 1000 & 0,0026 \\
Night wood & Diospyros sp. & 78 & 0,0002 \\
Taro & Caladium sp. & 40 & 0,0001 \\
White Salty & Ficus Benjamina & 1100 & 0,0029 \\
Fig & Ficus sp. & 65 & 0,0002 \\
Gayam & Inocarpus fagifer & 44 & 0,0001 \\
Guava & Syzgium sp. & 5 & 0,0001 \\
Fence distance & Ricinus communis & 65 & 0,0002 \\
Meta & Pometia pinnata & 90 & 0,0002 \\
Wheel & Ficus nodosa & 88 & 0,0002 \\
Rattan & Calamus sp. & 41 & 0,0001 \\
Breadfruit & Artocarpus altilis & 37 & 0,0001 \\
Waru & Hibiscus tiliaceus & 150 & 0,0004 \\
\hline
\end{tabular}

The results of the data collection of tree density in the buffer zone conservation area obtained that the highest density in the species Ficus Benjamina with the number of individuals as much as 1100 and the density of 0.0029 . While the lowest value of the tree is the type of Syzgium sp. with an individual number of 5 and a density value of 0.0001 .

\subsection{Index Distribution Results in the buffer zone area}

The distribution of forest tree species has different values between species. The results are contained in the table in the form of index values. The results of the index calculation can be seen in the table below.

Table4. Tree Index Value Distribution Results in Buffer Zone Area

\begin{tabular}{lllllllll}
\hline \multicolumn{1}{c}{ Local name } & \multicolumn{1}{c}{ Latin name } & K & KR\% & F & FRI & D & DR\% & FOR EXAMPLE \\
\hline Wants tuba & Derris elliptica & 6,25 & 3,88 & 0,30 & 4,76 & 1,60 & 2,78 & 11,42 \\
Night wood & Diospyros sp. & 2,08 & 1,29 & 0,11 & 1,79 & 0,57 & 0,99 & 4,07 \\
Taro & Caladium sp. & 1,39 & 0,86 & 0,07 & 1,19 & 0,42 & 0,72 & 2,78 \\
White Salty & Ficus Benjamina & 4,86 & 3,02 & 0,15 & 2,38 & 3,39 & 5,90 & 11,30 \\
Fig & Ficus sp. & 1,39 & 0,86 & 0,07 & 1,19 & 0,41 & 0,71 & 2,76 \\
Gayam & Inocarpus fagifer & 9,03 & 5,60 & 0,33 & 5,36 & 4,25 & 7,38 & 18,34 \\
Guava & Syzgium sp. & 11,11 & 6,90 & 0,48 & 7,74 & 2,69 & 4,68 & 19,31 \\
Fence distance & Ricinus communis & 0,69 & 0,43 & 0,04 & 0,60 & 0,15 & 0,26 & 1,29 \\
Matoa & Pometia pinnata & 22,22 & 13,79 & 0,74 & 11,90 & 8,42 & 14,63 & 40,33 \\
Wheel & Ficus nodosa & 6,94 & 4,31 & 0,30 & 4,76 & 2,43 & 4,22 & 13,29 \\
Rattan & Calamus sp. & 4,17 & 2,59 & 0,15 & 2,38 & 2,11 & 3,67 & 8,64 \\
Breadfruit & Artocarpus altilis & 4,17 & 2,59 & 0,19 & 2,98 & 1,06 & 1,84 & 7,41 \\
Waru & Hibiscus tiliaceus & 1,39 & 0,86 & 0,07 & 1,19 & 0,36 & 0,63 & 2,68 \\
\hline
\end{tabular}

The results of observations are known that the highest relative density is found in trees with poetic pinata or motor with a value of KR\% of 13.79 with an important value of 40.33 . While the lowest relative density value is found in the species sonneratia alba and Ricinus communis or Jrak Pagar with the same value KR\% of 0.43 and Important Value of 1.29. 


\subsection{Mangrove forest carbon biomass}

The results of carbon biomass measurements in mangrove conservation areas can be seen in the table below.

Table5. Mangrove forest biomass

\begin{tabular}{ccccc}
\hline Local Name & Latin name & $\begin{array}{c}\text { Biomass } \\
\text { (Tonnes/Ha) }\end{array}$ & C (Kg/ind) & $\begin{array}{c}\mathbf{C} \\
\text { (Tone/ind) }\end{array}$ \\
\hline Man Mangroves & Rhizopora mucronata & 0,01 & 33,61 & 0,34 \\
Mangrove Urap & Rhizopora stylosa & 0,02 & 81,62 & 0,82 \\
Ketapang & Terminalia catappa & 0,01 & 24,07 & 0,24 \\
Pedada & Sonneratia alba & 0,00 & 8,96 & 0,09 \\
Could & Bruiguiera gymnorrizha & 0,03 & 126,73 & 1,27
\end{tabular}

The results of carbon biomass measurements in mangrove conservation areas found that the highest value was found in putut mangrove species(Bruiguiera gymnorrizha) with a value of 0.06 tons / Ha, while the lowest value was in the species Pedada (Sonneratialba)with a value of less than 0.001 .

\subsection{Carbon biomass in the Buffer Zone area}

The results of carbon biomass measurements in mangrove conservation areas can be seen in the table below.

Table6. Tree biomass in the Buffer Zone area

\begin{tabular}{ccccc}
\hline Local Name & Latin name & $\begin{array}{c}\text { Biomass } \\
\text { (Tonnes/Ha) }\end{array}$ & C (Kg/ind) & $\begin{array}{c}\text { C } \\
\text { (Tone/ind) }\end{array}$ \\
\hline Wants tuba & Derris elliptica & 1,27 & 414,79 & 0,29 \\
Night wood & Diospyros sp. & 0,16 & 51,07 & 0,04 \\
Taro & Caladium sp. & 14,78 & 4825,62 & 3,35 \\
White Salty & Ficus Benjamina & 7,98 & 2606,19 & 1,81 \\
Fig & Ficus sp. & 1,08 & 352,68 & 0,24 \\
Gayam & Inocarpus fagifer & 13,19 & 4305,45 & 2,99 \\
Guava & Syzgium sp. & 0,37 & 120,60 & 0,08 \\
Fence distance & Ricinus communis & 1,68 & 547,26 & 0,38 \\
Meta & Pometia pinnata & 3,27 & 1068,29 & 0,74 \\
Wheel & Ficus nodosa & 1,57 & 513,87 & 0,36 \\
Rattan & Calamus sp. & 13,87 & 4528,29 & 3,14 \\
Breadfruit & Artocarpus altilis & 0,90 & 294,58 & 0,20 \\
Waru & Hibiscus tiliaceus & 1,59 & 518,84 & 0,36 \\
\hline
\end{tabular}

The results of carbon biomass measurements in the buffer zone area found that the highest value was found in keladi species(Caladium sp.) with a value of 14.78 tons / Ha, while the lowest value is found in the species of Night Wood(Diospyros sp. ) with a value of less than 0.01 .

\subsection{Total Uptake and Storage of Carbon RU VII Eunuch}

The results of measurements of carbon uptake and storage in mangrove conservation areas and buffer zones can be seen in the table below. 
Table5. Total Carbon Uptake and Storage Measurement Results

\begin{tabular}{lcc}
\hline & Mangrove Area & Buffer Zone Area \\
\hline Luas Area Program & 10,5 & 38,5 \\
CO Uptake 2 (Ton/Ha) & 8,97 & 160,45 \\
Carbon Storage (Tons/Ha) & 32,93 & 588,86 \\
\hline
\end{tabular}

The results of the analysis of carbon uptake and storage in the area of mangrove conservation programs and buffer zones obtained mixed results. Mangrove conservation area with an area of 10.5 ha obtained uptake of 8.97 tons, while in the buffer zone obtained a value of 160.45 tons. In the results of carbon storage in the mangrove area obtained a value of 32.93 tons and in the buffer zone area of 588.86 tons. The comparison of carbon uptake values in mangrove ecosystems and buffer zones can be seen in the figure below.

A

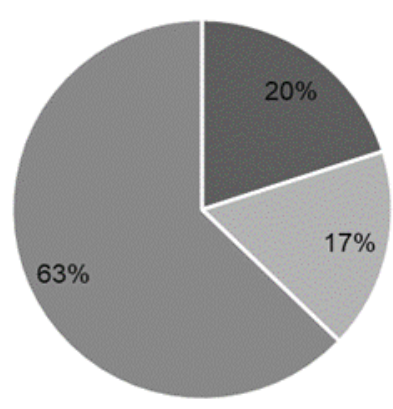

B

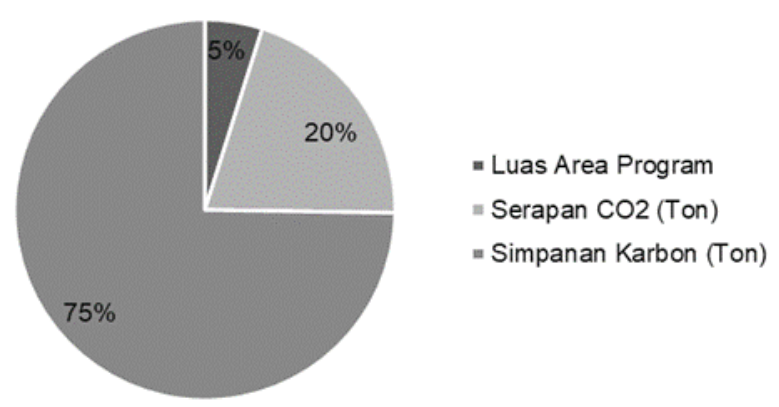

Figure 3. Comparison of area area with carbon storage and uptake, (A: Mangrove conservation area, B: Buffer Zone Area).

\section{DISCUSSION}

\subsection{Discussion of Tree Species Inventory in Mangrove and Buffer Zone areas}

Inventory of mangrove species in the conservation area of PT. Pertamina RU VII Kasim obtained 5 species. These species are Rhizopora mucronata, Rhizopora stylosa, Terminalia catappa, Sonneratia alba, and Bruiguiera gymnorrizha. According to Mukhlisi and Purnaweni (2013), it is said that the type of mangrove is a type of major component. Tomlinson further elaborated if the category of mangrove majors can form a pure stand and secrete salt water so that it can grow in inundated water. This type is the most common component found in mangrove conservation areas. This is following the opinion of Major et al., (2018) that the type is a mangrove found in West Papua. While the inventory of tree species in the buffer zone area was obtained, that identified 13 dominant tree species, namely Derris elliptica Diospyros sp., Caladium sp. , Ficus Benjamina, Ficus sp. , Inocarpus fagifer, Syzgium sp., Ricinus communis, Pometia pinnata, Ficus nodosa, Calamus sp. Artocarpus altilis, and Hibiscus tiliaceus. Based on Nugroho et al., (2019) that all types of trees are trees that can be found in West Papua.

The species with the highest importance indicates the value of species control in a community. The important value of a species can be used as an indication that the species is considered dominant by having a relative density value, relative frequency, and relative dominance that is higher than other species (Setiadi 2004).

In seedling mangrove forest formations, Mangrove plants of Rhizophora mucronate type dominate throughout the growth rate. This type has a NIALI INP of $91.22 \%$ at the tree level. This shows that the type R. mucronata has better adaptation power, competition, and reproductive power than other types in a mangrove forest community in the AREA PT. Pertamina (Persero) RU VII Kasim.

While in forest formations in the buffer zone area, Matoa Trees (Pometia pinnata)dominate with an INP value of $40.33 \%$, at the level of stake, pole, and tree. Matoa tree is the most widely found type of tree. di lokasi buffer zone. 
This type of tree is part of the arrangement of one forest ecosystem in the conservation area of PT. Pertamina (Persero) RU VII Kasim. So it needs to be preserved its existence.

\subsection{Carbon Storage in Conservation Areas}

Carbon content in mangrove areas obtained results of 32.93 tons / Ha. The area measured is 10.5 ha. The results were compared to research from Sofyan (2016) and Massugito (2016) where the carbon content of mangroves in mangrove areas amounted to 58-258 tons / Ha. From these results, there is a significant difference, where it is assumed that the area of mangrove areas in this study is different. According to Oktavian et al., (2017), the results obtained in his research amounted to 2-3 tons / Ha, wherein his research it is said that mangrove ecosystems have a high carbon storage potential. Based on the above, it was concluded that the mangrove ecosystem area at PT Pertamina RU VII Kasim has great potential in storing carbon content. So it is necessary to maintain conservation efforts so that mangrove ecosystems are maintained and can contribute to the preservation of nature in Indonesia. The carbon content in the buffer zone area gets a value of 588.86 tons / Ha. The difference in results with the mangrove ecosystem area is triggered due to the area of different areas, where the buffer zone area has an area of 38.5 ha. It can be concluded that these two regions have the potential to store large amounts of carbon.

\subsection{Carbon Uptake in Conservation Areas}

Carbon uptake in mangrove conservation areas was obtained from 8.97 tons/ha with an area of 10.5 ha. While in the buffer zone area obtained 160.45 tons/ha. This result when compared to Handoko's study (2016) with a value of 215.61 tons / Ha of eating saw a significant difference. This is due to differences in the area and density of trees in conservation areas both mangrove areas and buffer zones. However, from these results, it is also obtained that carbon uptake in two conservation areas of Pertamina RU VII eunuchs has the same high potential, so it is necessary to maintain conservation areas.

\subsection{Carbon Trading}

Hindarto and Samsyanugraha 2018 revealed that carbon has a selling point for countries that do not have forest areas. By 2021 the price of carbon per hectare will be $\$ 5 /$ ton. From the results of the measurements, the carbon stores from Pertamina RU VII Kasim's mangrove conservation and buffer zone program amounted to (345,765 tons for mangroves) and (22,671.11 for buffer zone areas). From these results in the calculation with the current carbon price, the first meal RU VII Kasim can potentially contribute to the state of Rp. 1,611,181,250 (1.6 billion) or \$115,084,375 (US Dollar).

\begin{tabular}{lcc}
\hline & Mangrove Area & Buffer Zone Area \\
\hline Luas Area Program & 10,5 & 38,5 \\
CO Uptake 2 $_{\text {(Ton/Ha) }}$ & 8,97 & 160,45 \\
Carbon Storage (Tons/Ha) & 32,93 & 588,86 \\
\hline
\end{tabular}

\section{Kesimpulan}

Carbon storage in mangrove areas amounted to 32.93 tons / Ha and in buffer zone areas amounted to 588.86 tons / Ha. While the uptake of carbon in mangrove ecosystems amounted to 8.97 tons / Ha and in the buffer zone area of 160.45 tons / Ha. In carbon trading, Pertamina RU VII Program can potentially be able to drive the country by (1.6 billion) at an exchange rate (14,000 US Dollars). 


\section{References}

[IPPC] Intergovernmental Panel on Climate Change, 2006, IPCC Guidelines for National Greenhouse Gas Inventories: Agriculture, Forestry and Other Land Use. Simon E, Leandro B, Kyoto M, Todd N, Kiyoto T, editor. Hayama (JP): The Institute for Global Environmental Strategies (IGES).

Badan Standardisasi Nasional, 2011, SNI 7724 - Pengukuran dan Perhitungan Cadangan Karbon - Pengukuran Lapangan untuk Penaksiran Cadangan Karbon Hutan (Ground Based Forest Carbon Accounting). Badan Standardisasi Nasional.

Djamaluddin, R, 2018, Mangrove-Biologi, Ekologi, Rehabilitasi, dan Konservasi.

Donato, D. C., J. B. Kauffman, D. Murdiyarso, S. Kurnianto, M. Stidham dan M. Kanninen, 2011, Mangroves Among the Most Carbon-Rich Forest in the Tropics. Nature Geoscience.

Handoko, E, 2016, Analisis Biomassa dan Cadangan Karbon pada Ekosistem Hutan Mangrove di Kawasan Pesisir Selatan Pulau Rupat Provinsi Riau. Skripsi pada Jurusan Ilmu Kelautan Fakultas Perikanan dan Kelautan Universitas Riau, Pekanbaru.

IPCC, 2006, Intergovernmental Panel on Climate Change (IPCC) Guidelines for national greenhouse Gas Inventories, Prepared by the National Greenhouse Gas Inventories Programme, Eggleston H. S., L. Buendia, K. Miwa, T. Ngara

Massugito, 2016, Analisis Cadangan Karbon pada Ekosistem Hutan Mangrove di Kawasan Pesisir Kuala Indragiri Provinsi Riau. Skripsi pada Jurusan Ilmu Kelautan Fakultas Perikanan dan Kelautan Universitas Riau, Pekanbaru.

Mayor, T., Simbala, H. E., dan Koneri, R, 2018, Biodiversitas Mangrove di Pulau Mansuar Kabupaten Raja Ampat Provinsi Papua Barat (The Biodiversity of Mangrove in the Mansuar Island Raja Ampat District West Papua Province). JURNAL BIOS LOGOS, 7(2), 41-48.

Mukhlisi, H. I., dan Purnaweni, H, 2013, Keanekaragaman jenis dan struktur vegetasi mangrove di desa Sidodadi kecamatan Padang Cermin Kabupaten Pesawaran, Provinsi Lampung. In Prosiding Seminar Nasional Pengelolaan Sumberdaya Alam dan Lingkungan (pp. 218-225).

Nugroho, Riyanto, A, Wiantoro S, Santika Y, Irham M, 2019. Ekpedisi Tambrauw, 2019 : Sepotong Surga di Tanah Papua. Lipi Press : Jakarta.

Oktaviona, S., Amin, B., \& Ghalib, M, 2017, Carbon Stock Assessment on Mangrove Forest Ecosystem in Jurong Ujuang Labuang District Agam West Sumatera Province (Doctoral dissertation, Riau University).

Qian, H., Bismarck, A., Greenhalgh, E. S., Kalinka, G., dan Shaffer, M. S, 2008, Hierarchical composites reinforced with carbon nanotube grafted fibers: the potential assessed at the single fiber level. Chemistry of Materials, 20(5), 1862-1869.

Soerianegara I dan Indrawan A. 2002. Ekosistem Hutan Indonesia. Bogor (ID): Laboratorium Ekologi Hutan, Fakultas Kehutanan IPB.

Sofyan, M, 2016, Analisis Biomassa dan Cadangan Karbon pada Ekosistem Hutan Mangrove di Kawasan Pesisir Rupat Utara Provinsi Riau. Skripsi pada Jurusan Ilmu Kelautan Fakultas Perikanan dan Kelautan Universitas Riau, Pekanbaru.

Sugiyono, 2008, Metode Penelitian Kuantitatif, Kualitatif dan R\&D. Bandung: Alfabeta.

Tomlinson, P.B. 1986. The Botany of mangroves. Cambridge University Press. Cambridge. The UK. 